\title{
Extracellular interleukin-17F has a protective effect in oral tongue squamous cell carcinoma
}

\section{Almahmoudi, Rabeia}

2018-10

Almahmoudi , R, Salem , A, Sievilaeinen, M , Sundquist , E , Almangush , A, Toppila-Salmi , S , Paavonen , T , Salo , T \& Al-Samadi , A 2018 , ' Extracellular interleukin-17F has a protective effect in oral tongue squamous cell carcinoma ' , Head \& Neck , vol. 40 , no. 10 , pp. 2155-2165 . https://doi.org/10.1002/hed.25207

http://hdl.handle.net/10138/306897

https://doi.org/10.1002/hed.25207

unspecified

publishedVersion

Downloaded from Helda, University of Helsinki institutional repository.

This is an electronic reprint of the original article.

This reprint may differ from the original in pagination and typographic detail.

Please cite the original version. 


\title{
Extracellular interleukin-17F has a protective effect in oral tongue squamous cell carcinoma
}

\author{
Rabeia Almahmoudi DDS' | Abdelhakim Salem DDS ${ }^{1,2}$ (D) | Meri Sieviläinen BDS ${ }^{1}$ |

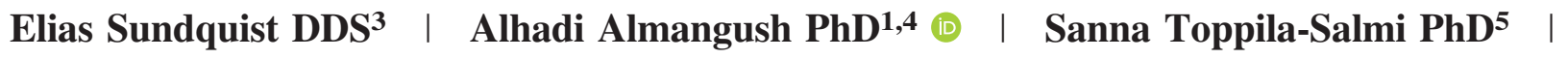 \\ Timo Paavonen PhD ${ }^{6}$ | Tuula Salo PhD ${ }^{1,2,7,8}$ | Ahmed Al-Samadi PhD ${ }^{1}$ \\ ${ }^{1}$ Department of Oral and Maxillofacial Diseases, Clinicum, University of Helsinki, Helsinki, Finland \\ ${ }^{2}$ Department of Clinical Medicine, Clinicum, University of Helsinki, Helsinki, Finland \\ ${ }^{3}$ Cancer and Translational Medicine Research Unit, University of Oulu, Oulu, Finland \\ ${ }^{4}$ Department of Pathology, University of Helsinki, Helsinki, Finland \\ ${ }^{5}$ Department of Allergy, University of Helsinki and Helsinki University Hospital, Helsinki, Finland \\ ${ }^{6}$ Department of Pathology, Fimlab Laboratories, Tampere University Hospital, Tampere, Finland \\ ${ }^{7}$ Medical Research Centre, Oulu University Hospital, Oulu, Finland \\ ${ }^{8}$ Department of Diagnostics and Oral Medicine, Research Group of Cancer Research and Translational Medicine, Medical Faculty, University of Oulu, Oulu, \\ Finland
}

\section{Correspondence}

Ahmed Al-Samadi, Department of Oral and Maxillofacial Diseases, Clinicum,

Biomedicum Helsinki 1, C223b P.O. Box 63 (Haartmaninkatu 8), 00014 University of Helsinki, Helsinki, Finland.

Email: ahmed.al-samadi@helsinki.fi

\section{Funding information}

The authors acknowledge the funders of this study: Sigrid Jusélius Foundation, the Cancer Society of Finland, Oulu University Hospital MRC grant, Emil Aaltonen Foundation, and Helsinki University Central Hospital Research Funds

\begin{abstract}
Background: Oral tongue squamous cell carcinoma (SCC) is characterized by early metastasis and poor prognosis. Interleukin-17F (IL-17F) plays a protective role in many tumors. However, IL-17F expression in oral tongue SCC tissue has not been investigated.

Methods: Immunostaining of 83 oral tongue SCC specimens and blinded-scoring were used to map IL-17F expression, location, and distribution. Survival curves were constructed according to Kaplan-Meier method. The Cox proportional hazard model was applied for univariate and multivariate survival analyses.

Results: Mast cells are the major source of IL-17F in oral tongue SCC. In multivariate analysis, only the extracellular mast cell-derived IL-17F at the tumor invasion front was associated with better disease-specific survival in patients with all-stages and earlystages of oral tongue SCC.

Conclusion: Extracellular mast cell-derived IL-17F is antitumorigenic in oral tongue SCC. It separates patients with early-stage disease who are at high risk from patients who are at low risk. Furthermore, when analyzing tentative prognostic molecules, we conclude that in addition to the staining intensity, attention must be paid to the cellular source, distribution, and location of the molecule.
\end{abstract}

\section{K E Y W O R D S}

interleukin-17F, mast cells, prognosis, squamous cell carcinoma, tongue 


\section{1 | INTRODUCTION}

Oral tongue squamous cell carcinoma (SCC) is the most common type of oral cancer worldwide and accounts for more than half of the malignant lesions in the oral cavity. ${ }^{1,2}$ The incidence rate of oral tongue SCC has increased recently. This increase is linked to several factors, including increased consumption of alcohol and tobacco products. ${ }^{3-5}$ Despite improved treatment approaches, oral tongue SCC therapy remains challenging because of rapid local invasion and early metastasis of the tumor cells to regional lymph nodes. ${ }^{6}$

Interleukin-17F (IL-17F) is the most recently characterized member of the IL-17 cytokine family. This family includes 6 IL-17 cytokines, namely, IL-17A through F. Of

TABLE 1 Baseline characteristics of patients with oral tongue squamous cell carcinoma

\begin{tabular}{|c|c|}
\hline Patient clinical data & $\begin{array}{l}\text { Total no. of } \\
\text { patients }(\%)\end{array}$ \\
\hline \multicolumn{2}{|l|}{ Age, years } \\
\hline$<60$ & $29(34.9)$ \\
\hline$\geq 60$ & $54(65.1)$ \\
\hline Range & $17-88$ \\
\hline Mean & 64.23 \\
\hline Median & 66 \\
\hline \multicolumn{2}{|l|}{ Sex } \\
\hline Male & $48(57.8)$ \\
\hline Female & $35(42.2)$ \\
\hline \multicolumn{2}{|l|}{ Tumor grade } \\
\hline I, well & $21(25.3)$ \\
\hline II, moderate & $53(63.9)$ \\
\hline III, poor & $9(10.8)$ \\
\hline \multicolumn{2}{|l|}{ Tumor stage } \\
\hline Early, I-II & $49(59)$ \\
\hline Late, III-IV & $34(41)$ \\
\hline \multicolumn{2}{|l|}{ Depth of invasion } \\
\hline$<4 \mathrm{~mm}$ & $18(21.7)$ \\
\hline$\geq 4 \mathrm{~mm}$ & $65(78.3)$ \\
\hline \multicolumn{2}{|l|}{ Neck lymph nodes } \\
\hline Positive & $33(39.8)$ \\
\hline Negative & $50(60.2)$ \\
\hline \multicolumn{2}{|l|}{ Adjuvant therapy } \\
\hline No & $39(47)$ \\
\hline Radiochemotherapy & $24(28.9)$ \\
\hline Radiochemotherapy and chemotherapy & $20(24.1)$ \\
\hline \multicolumn{2}{|l|}{ Recurrence } \\
\hline No & $47(56.6)$ \\
\hline Yes & $36(43.4)$ \\
\hline
\end{tabular}

TABLE 2 Primary antibodies used for the immunofluorescence staining

\begin{tabular}{cll}
\hline Antibody & Source & $\begin{array}{c}\text { Working dilution/ } \\
\text { concentration }\end{array}$ \\
\hline $\begin{array}{c}\text { Goat anti-human, } \\
\text { polyclonal, IL-17F }\end{array}$ & $\begin{array}{c}\text { R\&D Systems, } \\
\text { Minneapolis, MN }\end{array}$ & $1: 100(1 \mu \mathrm{g} / \mathrm{mL})$ \\
$\begin{array}{c}\text { Rabbit anti-human, } \\
\text { monoclonal, mast } \\
\text { cell tryptase }\end{array}$ & $\begin{array}{c}\text { Abcam, } \\
\text { Cambridge, UK }\end{array}$ & $1: 500(1 \mu \mathrm{g} / \mathrm{mL})$ \\
\hline $\begin{array}{c}\text { Mouse anti-human, } \\
\text { monoclonal, CD8 }\end{array}$ & $\begin{array}{c}\text { Dako, Glostrup, } \\
\text { Denmark }\end{array}$ & $1: 100(1.5 \mu \mathrm{g} / \mathrm{mL})$ \\
\hline $\begin{array}{c}\text { Mouse anti-human, } \\
\text { monoclonal, CD4 }\end{array}$ & $\begin{array}{c}\text { Dako Cytomation, } \\
\text { Glostrup, Denmark }\end{array}$ & $1: 80(3 \mu \mathrm{g} / \mathrm{mL})$ \\
\hline $\begin{array}{c}\text { Mouse anti-human } \\
\text { monoclonal, CD56 }\end{array}$ & $\begin{array}{c}\text { Dako Cytomation, } \\
\text { Glostrup, Denmark }\end{array}$ & $1: 100(3.62 \mu \mathrm{g} / \mathrm{mL})$ \\
\hline $\begin{array}{c}\text { Mouse anti-human, } \\
\text { monoclonal, CD20 }\end{array}$ & $\begin{array}{c}\text { Dako Cytomation, } \\
\text { Glostrup, Denmark }\end{array}$ & $1: 200(1.92 \mu \mathrm{g} / \mathrm{mL})$ \\
\hline $\begin{array}{c}\text { Mouse anti-human, } \\
\text { monoclonal, CD163 }\end{array}$ & $\begin{array}{c}\text { Leica Biosystems, } \\
\text { Newcastle, UK }\end{array}$ & $1: 200(15.5 \mu \mathrm{g} / \mathrm{mL})$ \\
\hline
\end{tabular}

Abbreviation: IL, interleukin.

all IL-17 members, IL-17F shares the greatest homology with IL-17A. ${ }^{7}$ Unlike IL-17A, which is known as a protumorigenic cytokine, IL-17F was shown to have an antitumorigenic effect in several cancer types through different mechanisms. ${ }^{8} 9$ In colon cancer, IL-17F was reported as an inhibitory molecule of tumor angiogenesis; we also showed that IL-17F levels were significantly lower than those in nonmalignant control samples. ${ }^{10,11}$ Moreover, IL-17F inhibits the proliferation of hematopoietic malignant cells, such as mastocytoma and plasmocytoma. ${ }^{12}$ In addition, IL-17F provides a protective effect against hepatocellular carcinoma through the inhibition of tumor angiogenesis. ${ }^{13}$ Interestingly, IL-17F levels were lower in the serum of patients with oral cancer than in the serum of patients with leukoplakia and healthy controls. ${ }^{14}$ Altogether, such reports apparently suggest an inverse relationship between IL-17F and tumorigenesis. However, local IL-17F expression and its putative role in oral tongue SCC remain unknown. In this study, we evaluated the cellular sources of IL-17F in oral tongue SCC tissue sections and investigated its possible association with patients' prognosis and mortality.

\section{2 | MATERIALS AND METHODS}

This study was performed according to the REMARK guidelines for tumor marker prognostic studies. ${ }^{15}$ 
TABLE 3 Scoring criteria of oral tongue squamous cell carcinoma specimens

\begin{tabular}{|c|c|}
\hline Score & Description \\
\hline \multicolumn{2}{|c|}{ Inflammatory cell distribution } \\
\hline 0 & $\begin{array}{l}\text { Inflammatory cells are distributed mainly } \\
\text { in the tumor area }\end{array}$ \\
\hline 1 & $\begin{array}{l}\text { Inflammatory cells are distributed mainly } \\
\text { in the invasion front }\end{array}$ \\
\hline 2 & $\begin{array}{l}\text { Inflammatory cells are distributed evenly } \\
\text { in both areas }\end{array}$ \\
\hline \multicolumn{2}{|c|}{ IL-17F expression by cancer cells } \\
\hline 0 & Negative \\
\hline 1 & $5 \%-75 \%$ of cancer cells are IL-17F-positive \\
\hline 2 & $>75 \%$ of cancer cells are IL-17F-positive \\
\hline \multicolumn{2}{|c|}{ Inflammatory cell type } \\
\hline 1 & Predominance of mast cells over inflammatory cells \\
\hline 2 & Predominance of inflammatory cells over mast cells \\
\hline \multicolumn{2}{|c|}{ IL-17F localization within mast cells } \\
\hline 1 & $\begin{array}{l}\text { IL-17F is expressed both intracellularly } \\
\text { and at the extracellular matrix }\end{array}$ \\
\hline 2 & IL-17F is expressed only intracellularly \\
\hline
\end{tabular}

Abbreviation: IL, interleukin.

\section{1 | Patients}

This multicenter study comprised 83 patients with oral tongue SCC who were treated surgically at the Oulu and Tampere University Hospitals during the period from 19902010. Paraffin-embedded samples were obtained from the Departments of Pathology at the Oulu and Tampere University Hospitals. All patients signed informed consent forms.

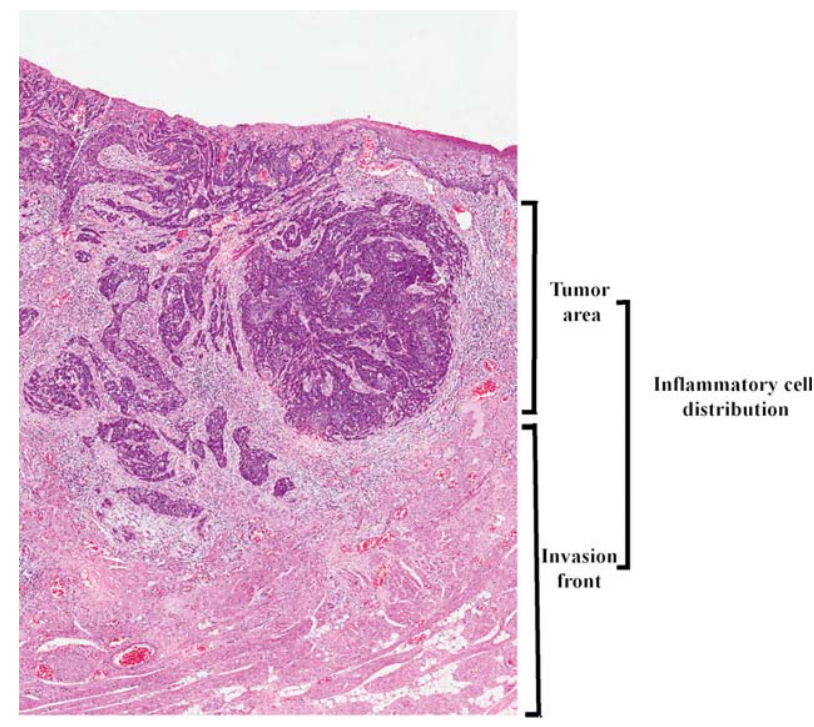

FIG URE 1 The scoring of the inflammatory cell distribution was carried out in 2 areas: the tumor area and the invasion front (original magnification $\times 2$ ) [Color figure can be viewed at wileyonlinelibrary.com]
TABLE 4 Scoring results of oral tongue squamous cell carcinoma specimens

\begin{tabular}{|ll}
\hline Variables & No. of patients $(\%)$ \\
\hline Inflammatory cell pattern & \\
0 & $14(16.9)$ \\
1 & $22(26.5)$ \\
2 & $47(56.6)$ \\
\hline IL-17F expression by cancer cells & \\
0 & $63(75.9)$ \\
1 & $15(18.1)$ \\
2 & $5(6)$ \\
\hline
\end{tabular}

Inflammatory cell type (invasion front)

$$
\begin{array}{ll}
1 & 50(60.2) \\
2 & 33(39.8)
\end{array}
$$

Inflammatory cell type (tumor area)

1

$14(16.9)$

$67(80.7)$

IL-17F localization within mast cells (invasion front)

$$
\begin{array}{ll}
1 & 54(65.1) \\
2 & 29(34.9)
\end{array}
$$

Abbreviation: IL, interleukin.

The data inquiry was approved by the National Supervisory Authority for Welfare and Health (VALVIRA) and the Ethics Committee of the Northern Ostrobothnia Hospital District. The use of patient material for this study was approved by the Northern Ostrobothnia Hospital District Ethics Committee (statement \#8/2006 and amendment 19/10/ 2006). Detailed patient data are presented in Table 1.

\subsection{Immunohistochemical staining}

Paraffin-embedded samples were cut into 5- $\mu \mathrm{m}$-thick sections using Leica RM2255 microtome (Leica Microsystems, Wetzlar, Germany). Immunohistochemical staining was performed using the Goat on Rodent HRP-polymer kit (Biocare Medical, Pacheco, CA). After deparaffinization, antigens were retrieved in citrate buffer (Dako, Carpinteria, CA) for 15 minutes using a microwave and followed by 20-minute cooling at room temperature. Endogenous peroxidase activity was blocked with Dako Peroxidase blocking solution for 15 minutes. Polyclonal goat antihuman IL-17F primary antibody (R\&D Systems, Minneapolis, MN) at a concentration of 1 $\mu \mathrm{g} / \mathrm{mL}$ was applied first for 30 minutes at $37^{\circ} \mathrm{C}$ then overnight at $4^{\circ} \mathrm{C}$. On the following day, goat probe was applied for 15 minutes and followed by Goat on Rodent HRP- 

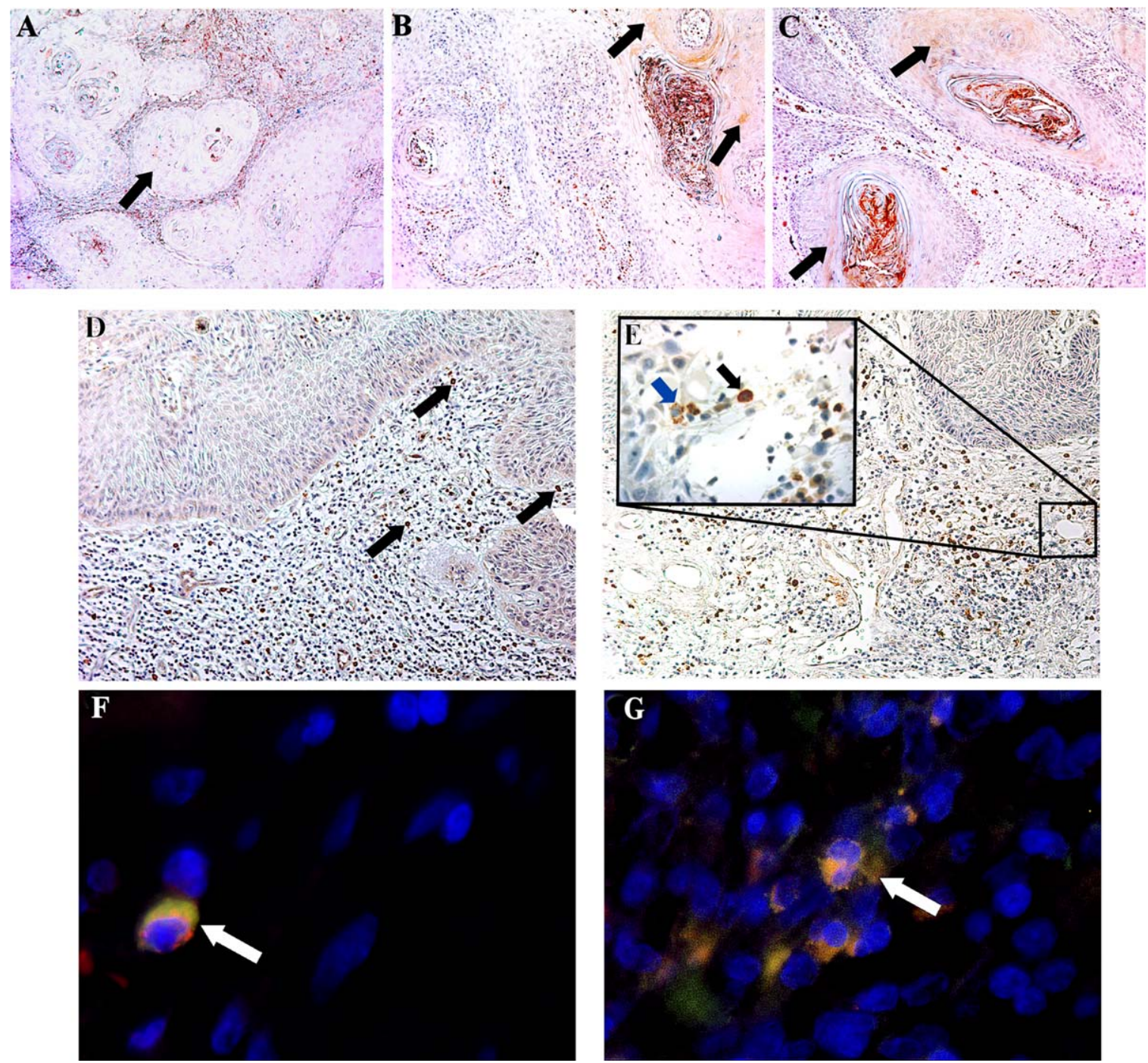

FIG URE 2 Expression of interleukin (IL)-17F by oral tongue squamous cell carcinoma (SCC) cells. A, Tumor cells (black arrows) were IL-17Fnegative for most patients with oral tongue SCC. B, In other cases, 5\%-75\% of tumor cells (black arrows) were IL-17F-positive; C, in a few cases, $>75 \%$ of tumor cells (black arrows) were IL-17F-positive. D, Inflammatory cells (black arrows) showed strong expression for IL-17F. E, Expression of IL-17F was detected in mast cells both intracellularly (black arrow) and extracellularly (blue arrow). Double immunofluorescence staining for IL-17F (green), mast cell tryptase (red), and DAPI (blue) confirmed the presence of both the intracellular (white arrow, F) and extracellular (white arrow, G) patterns of IL-17F expression. Original magnification $\mathrm{A}-\mathrm{D}=\times 10 ; \mathrm{E}=\times 63$; and $\mathrm{F}-\mathrm{G}=\times 100$ [Color figure can be viewed at wileyonlinelibrary.com]

polymer for 15 minutes at room temperature. Color was developed using diaminobenzidine tetrahydrochloride for 10 minutes and washed in $\mathrm{dH}_{2} \mathrm{O}$. Counterstaining of the slides was performed using Mayer's hematoxylin solution (SigmaAldrich, St. Louis, MO) and mounted in Mountex (HistoLab, Gothenburg, Sweden).

\section{3 | Immunofluorescence staining}

After deparaffinization, antigen retrieval was performed using a microwave oven (MicroMED T/T Mega Histoprocessing Labstation; Milestone Srl, Sorisole, Italy). Slides were then treated with $0.5 \%$ triton $\mathrm{X}-100$ for 10 minutes at room temperature. Slides were washed 3 times (5 minutes each wash) in phosphate-buffered saline (PBS) and incubated in $10 \%$ normal serum for 1 hour. Serum was subsequently blotted away and slides were incubated overnight at $4^{\circ} \mathrm{C}$ in primary antibodies (detailed antibody information is listed in Table 2). Slides were washed 3 times (5 minutes each wash) in PBS and incubated in fluorescein-conjugated secondary antibodies (Alexa Fluor, Molecular Probes, Leiden, The Netherlands) for 1 hour at room temperature. After 3 washes (5 minutes each wash) in PBS, nuclei were counterstained with 4',6-diamidino-2- phenylindole (DAPI; Sigma-Aldrich) for 10 minutes at room temperature. Slides were mounted in Vectashield mounting medium (Vector Laboratories, Burlingame, CA). The specificity of each staining was confirmed with staining controls. 

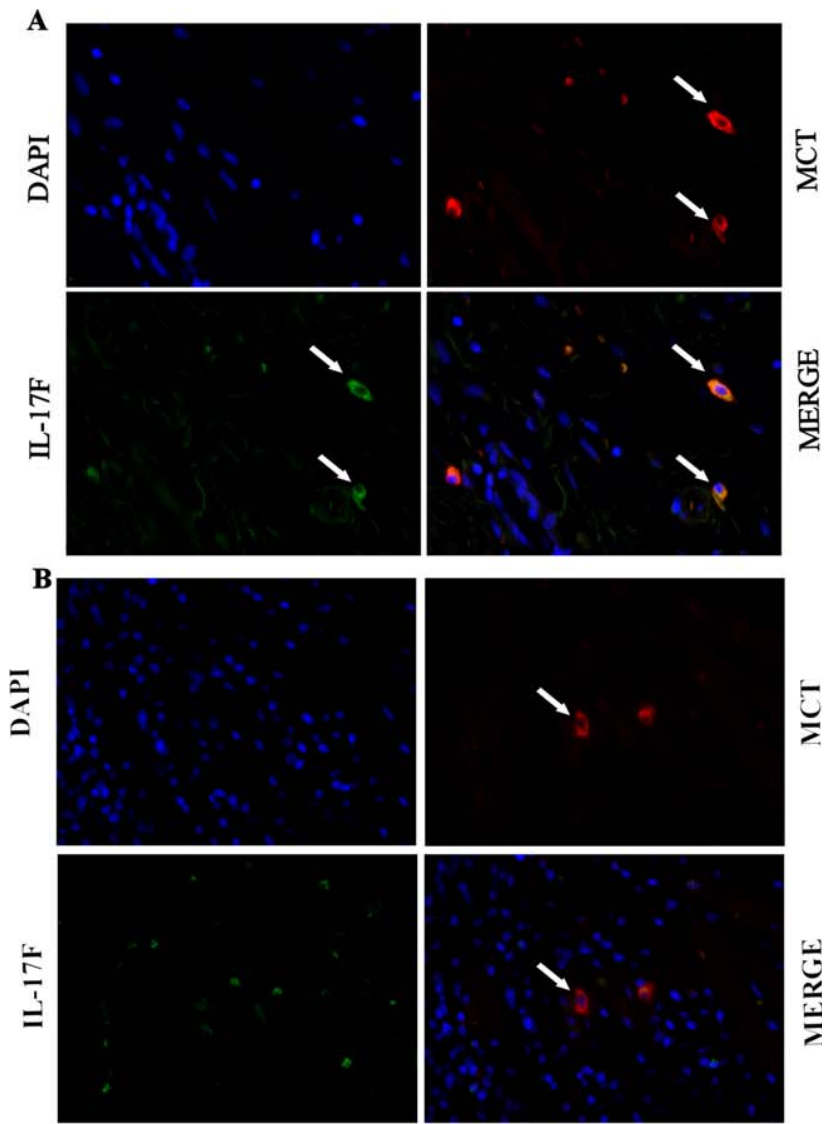

C

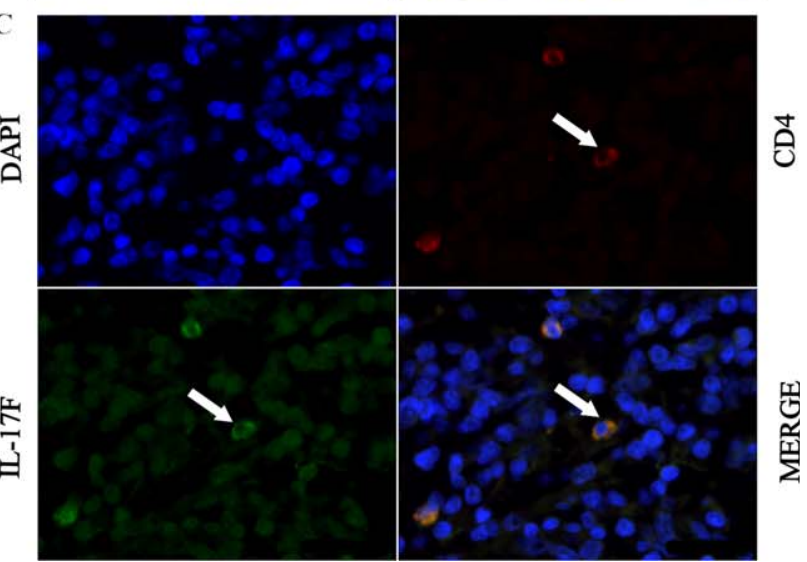

FIGURE 3 Double immunofluorescence staining of interleukin (IL)-17F and inflammatory cell markers in oral tongue squamous cell carcinoma (SCC) tissues. A, Most of the mast cells expressed strong IL-17F staining: blue $=$ nuclei $(\mathrm{DAPI})$; red $=$ mast cell tryptase; green $=\mathrm{IL}-17 \mathrm{~F}$. $\mathrm{B}$, Some of the mast cells were negative for IL-17F. C, For CD4-positive T helper cells, some cells showed faint IL-17F immunoreactivity; blue = nuclei (DAPI); red = CD4; and green $=$ IL-17F (original magnification $\times 40$ [Color figure can be viewed at wileyonlinelibrary.com]

\subsection{Assessment of interleukin-17F expression}

Two independent researchers (R.A. and M.S.) analyzed IL17F staining; both researchers were blinded to the clinical data. The scoring criteria are listed in Table 3. Inflammatory cell distribution was scored in the tumor area and in the invasion front (Figure 1). The number of IL-17F-positive mast cells in the tumor area and invasion front was counted from 3 randomly selected $20 \times$ magnification fields per slide.

\subsection{Imaging of stained specimens}

A fully automated Leica DM6000 microscope together with Leica DFC365-FX camera (Leica Microsystems) and a BX61 Motorized System Microscope (Olympus Life and Material Science Europa GmbH, Hamburg, Germany) were used to image the immunostained slides. Representative figures are presented in the Results section.

\subsection{Statistical analysis}

Statistical analyses were performed using SPSS software program version 24.0 (IBM SPSS Statistics, SPSS, Chicago, IL). Life tables were calculated according to the Kaplan-Meier method. Survival curves were compared with the log-rank test. Univariate and multivariate survival analyses were performed with the Cox's proportional hazards model. In multivariate analysis, the results were adjusted for age, sex, grade, stage, depth of invasion, and lymph node metastasis. Because there were no end points (cancer deaths) in the $<4$-mm depth of invasion group among patients with early-stage oral tongue SCC, no hazard ratios (HRs) could be calculated in reference to this group. The Mann-Whitney $U$ test was used to check the statistical significance between the 2 groups. In all the analyses, values $\leq .05$ were regarded as statistically significant.

\section{3 | RESULTS}

\subsection{Inflammatory cells are evenly distributed within oral tongue squamous cell carcinoma}

We first examined the distribution of inflammatory cells in the scored layers of oral tongue SCC samples. The most frequently observed pattern of the inflammatory cell infiltrate in oral tongue SCC tissues was even distribution in the 2 areas (56.6\%) followed by a greater density of inflammatory cells in the invasion front area (26.5\%) and in the tumor area (16.9\%; Table 4).

\subsection{Mast cells are the major producer of interleukin-17F in oral tongue squamous cell carcinoma}

We next analyzed the immunoexpression of IL-17F in cancer and inflammatory cells. Cancer cells were IL-17F-negative for the majority of the patients with oral tongue SCC (75.9\%); cancer cells positive for IL-17F were observed in some patients (24.1\%; Figure 2A-C; Table 4). Inflammatory cells 

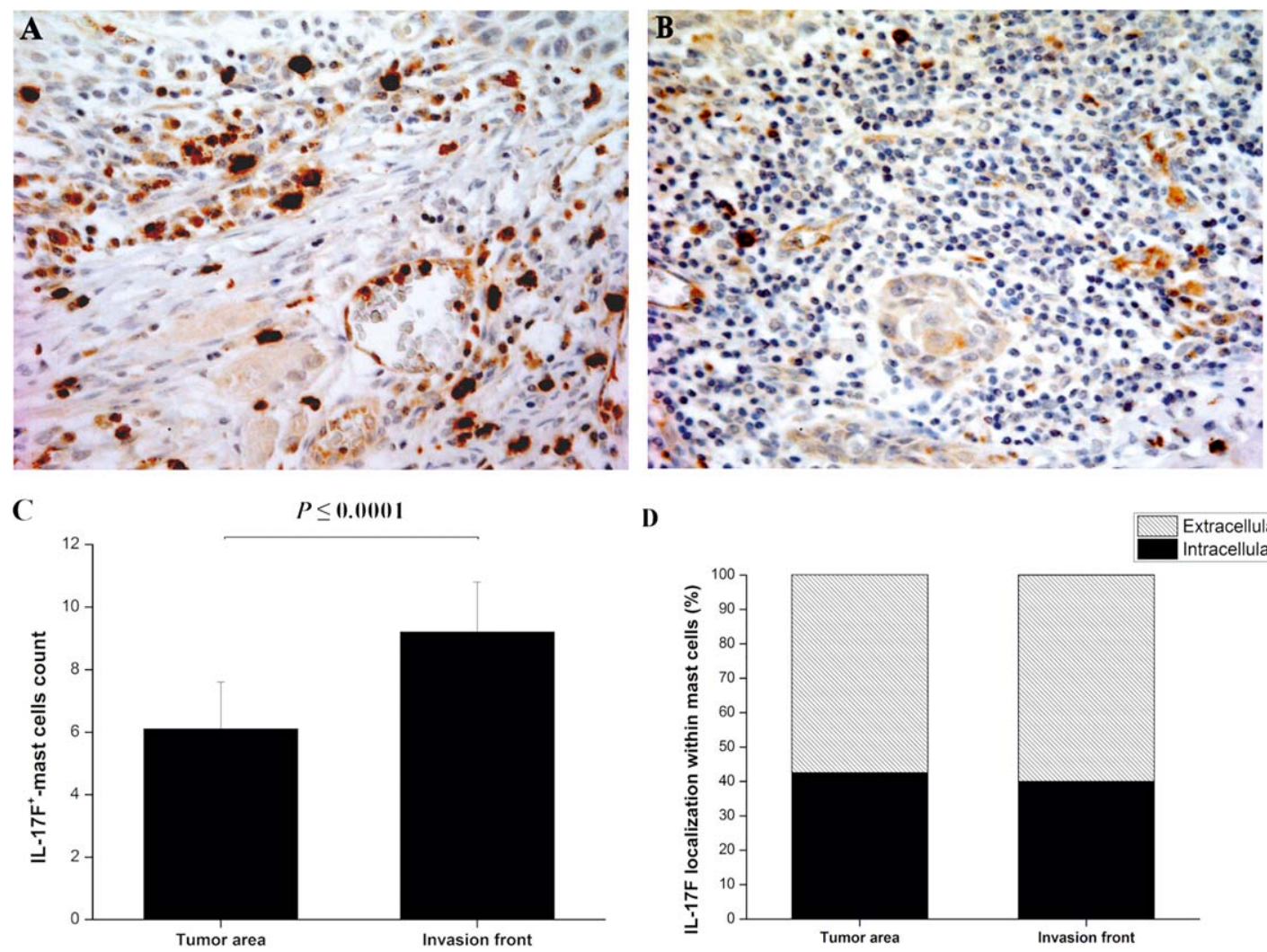

D

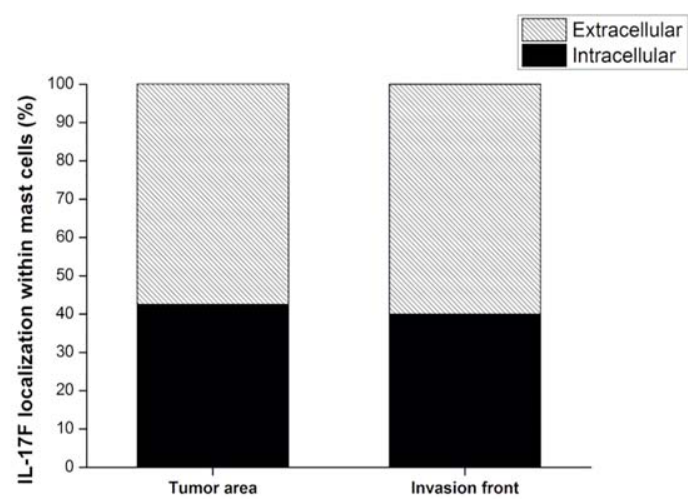

F I G URE 4 Inflammatory cell type in oral tongue squamous cell carcinoma (SCC). A, Mast cells were more frequent at the invasion front of oral tongue SCC tissues. B, The other inflammatory cells were more frequent in the tumor area closer to the epithelial tissue. C, The count of interleukin (IL)17F-positive mast cells was significantly higher in the invasion front compared to the tumor area. D, Extracellular pattern of IL-17F from mast cells was more frequent than the intracellular pattern both at the tumor area and at the invasion front (original magnification $\times 40$ [Color figure can be viewed at wileyonlinelibrary.com]

showed sporadically strong IL-17F expression (Figure 2D). The IL-17F staining in the cells that have mast cell morphology was either in the cytoplasm (intracellular) or extracellular (Figure 2E). Double immunofluorescence staining using IL$17 \mathrm{~F}$ and mast cell tryptase antibodies confirmed the 2 patterns of the staining (Figure 2F,G). Staining with both inflammatory cell markers and IL-17F demonstrated that the majority of mast cells were positive for IL-17F (Figure 3A) and only a few were negative (Figure 3B). Some CD4-positive T helper cells exhibited weak IL-17F immunoreactivity (Figure 3C). On the other hand, CD20-positive B cells, CD8-positive $\mathrm{T}$ cells, and CD163-positive macrophages were negative for IL-17F (data not shown).

\section{3 | Mast cells positive for interleukin-17F are more common at the invasion front in oral tongue squamous cell carcinoma}

Mast cells positive for IL-17F were often seen in the invasion front (60.2\%; Figure 4A; Table 4). Other inflammatory cells positive for IL-17F were more commonly located in the tumor area (80.7\%; Figure 4B; Table 4) and to a lesser extent in the invasion front (39.8\%; Table 4). The IL-17F-positive mast cell count was higher in the invasion front compared to the tumor area $(P<.0001$; Figure $4 \mathrm{C})$.

\subsection{Extracellular mast cell interleukin-17F expression is predominant in oral tongue squamous cell carcinoma}

Extracellular IL-17F from mast cells was predominant in $65.1 \%$ of patients at the invasion front and $74.7 \%$ of patients at the tumor areas (Table 4). Additionally, extracellular IL$17 \mathrm{~F}$ from mast cells represented $57.4 \%$ of the total IL-17Fpositive mast cells at the tumor area and $59.9 \%$ at the invasion front (Figure 4D).

\section{5 | Extracellular interleukin-17F from the invasion-front mast cells predicts the survival outcome of patients with oral tongue squamous cell carcinoma}

We applied univariate analyses for the mast cell extracellular IL-17F on cancer-specific deaths. Patients with extracellular IL-17F in the invasion front had longer disease-specific survival (DSS) compared with patients with intracellular IL-17F 

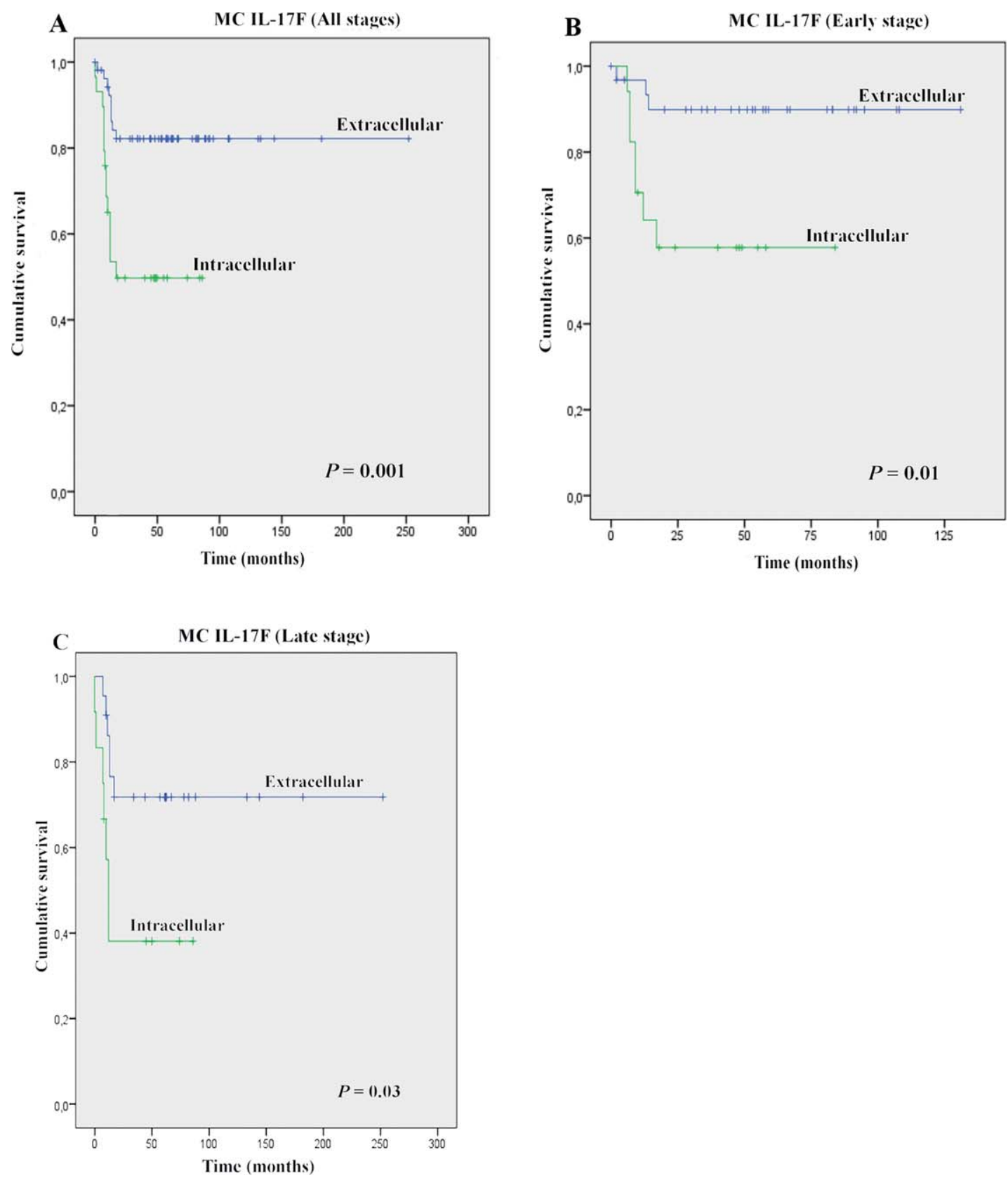

F I G U RE 5 Survival curves of the invasion front mast cell interleukin (IL)-17F location in all stages, early-stage and late-stage oral tongue squamous cell carcinoma (SCC). A, Kaplan-Meier curves representing the mast cell IL-17F location in all stages, B, early-stage, and C, late-stage of patients with oral tongue SCC [Color figure can be viewed at wileyonlinelibrary.com]

expression. This was shown in all stages (HR 3.79, 95\% confidence interval $[\mathrm{CI}] 1.64-8.80, P=.001$; Figure $5 \mathrm{~A}$, Table 5), in patients with early-stage (HR 4.99, 95\% CI 1.28-19.38, $P=.01$; Figure 5B, Table 6) and late-stage (HR 3.34, 95\% CI 1.11-10.06, $P=.03$; Figure $5 \mathrm{C}$, Table 7) oral tongue SCC.

Additionally, multivariate Cox's proportional hazard regression model analysis was built to evaluate further the impact of IL-17F expression on DSS $(\mathrm{n}=83 ; 54$ events). The IL-17F extracellular staining was significantly associated with longer DSS in all stages (HR $3.24,95 \%$ CI $1.35-7.79, P=.008)$, in patients with early-stage (HR 4.18, 95\% CI 1.01-17.26, $P=.04$ ) but not with late-stage (HR 2.28, 95\% CI 0.69-7.48, $P=.17)$ oral tongue SCC.

\section{4 | DISCUSSION}

Although IL-17F-mediated immunity is considered as a crucial host defense mechanism against infections, IL-17F is now believed to play a pivotal role in tumorigenesis. ${ }^{10-14}$ In the present study, we showed for the first time that the extracellular localization of IL-17F from mast cells at the 
TABLE 5 Cox regression univariate and multivariate analyses of disease-specific survival for patients with all stages of oral tongue squamous cell carcinoma

\begin{tabular}{|c|c|c|c|c|}
\hline Variables & \multicolumn{2}{|c|}{ Univariate analysis } & \multicolumn{2}{|c|}{ Multivariate analysis } \\
\hline \multicolumn{5}{|l|}{ Age, years } \\
\hline$<60$ & 1 & & 1 & \\
\hline$\geq 60$ & $2.51(0.93-6.76)$ & .06 & $2.72(0.88-8.33)$ & .08 \\
\hline Male & $1.99(0.87-4.55)$ & .10 & $1.93(0.77-4.83)$ & .16 \\
\hline \multicolumn{5}{|l|}{ Tumor grade } \\
\hline I and II & 1 & & 1 & \\
\hline III & $1.77(0.60-5.19)$ & .30 & 2. $32(0.70-7.65)$ & .17 \\
\hline \multicolumn{5}{|c|}{ Depth of invasion } \\
\hline$\geq 4 \mathrm{~mm}$ & $1.42(0.48-4.18)$ & .52 & 1. $35(0.42-4.34)$ & .62 \\
\hline \multicolumn{5}{|l|}{ Tumor stage } \\
\hline Early, I-II & 1 & & 1 & \\
\hline Late, III-IV & $2.01(0.87-4.57)$ & .09 & $1.51(0.53-4.29)$ & .43 \\
\hline \multicolumn{5}{|c|}{ Lymph node metastasis } \\
\hline $\mathrm{N}_{0}$ & 1 & & 1 & \\
\hline $\mathrm{N}_{1}$ & $1.94(0.85-4.43)$ & .11 & $1.90(0.63-5.69)$ & .25 \\
\hline \multicolumn{5}{|c|}{ IL-17F localization for mast cells } \\
\hline
\end{tabular}

Abbreviations: CI, confidence interval; HR, hazard ratio; IL, interleukin.

Figures in boldface indicate statistical significance.

invasion front is associated with improved overall survival and prognostic outcomes for patients with oral tongue SCC.

Cancer cells produce various cytokines and chemokines that recruit immune cells to the tumor site. Indeed, the inflammatory component of the tumor microenvironment includes a wide range of inflammatory cells, including neutrophils, macrophages, lymphocytes, and mast cells. These cells can synthesize and produce a large amount of cytokines and cytotoxic mediators. ${ }^{16,17}$ Among these cells, mast cells are regarded as highly important components of the tumor microenvironment and are involved in orchestrating immune responses against the tumor cells. ${ }^{18}$ Furthermore, we showed in a recent study that mast cell count was noticeably increased in specimens of patients with oral tongue SCC compared with those retrieved from patients with oral dysplasia and normal controls. ${ }^{19}$ In this context, it is interesting to find that IL-17F immunoreactivity was most intense in mast cells compared with the other inflammatory infiltrate cells, such as lymphocytes. This finding suggests that mast cells are the major cellular source of IL-17F in patients with oral tongue SCC, which is consistent with other reports that highlighted mast cells (as opposed to $\mathrm{T}$ cells) as the main producers of IL-17F in human dermal tissue. ${ }^{20}$

Inflammatory cell distribution and interaction in tissues are considered as significant features in interpreting the therapeutic outcomes of many tumors. ${ }^{16,21}$ We recently observed such an interaction between cancer and inflammatory cells in a $3 \mathrm{D}$ human-derived in vitro model that demonstrated the ability of inflammatory cells to influence cancer cell proliferation and invasion. ${ }^{22}$ Furthermore, our group previously found a significant correlation between inflammatory cell infiltrates and oral tongue SCC recurrence. ${ }^{23}$ In particular, we reported that patients with samples rich in CD163positive cells, Foxp3-positive regulatory T cells, and CD80positive cells showed higher incidence of cancer recurrence than in patients with a lower abundance of such cells. ${ }^{23}$ However, our findings in the present study suggest a nonsignificant correlation between the morphometrical distribution of the total inflammatory cells and the clinical status of patients with all-stages of oral tongue SCC. 
TABLE 6 Cox regression univariate and multivariate analyses of disease-specific survival for patients with early-stage oral tongue squamous cell carcinoma

\begin{tabular}{|c|c|c|c|c|}
\hline Variable & \multicolumn{2}{|c|}{ Univariate analysis } & \multicolumn{2}{|c|}{ Multivariate analysis } \\
\hline \multicolumn{5}{|l|}{ Age, years } \\
\hline$<60$ & 1 & & 1 & \\
\hline$\geq 60$ & $2.35(0.49-11.05)$ & .28 & $2.17(0.33-14.41)$ & .41 \\
\hline \multicolumn{5}{|l|}{ Sex } \\
\hline Male & $2.21(0.62-7.85)$ & .22 & $2.41(0.40-14.41)$ & .33 \\
\hline \multicolumn{5}{|l|}{ Tumor grade } \\
\hline I and II & 1 & & 1 & \\
\hline III & $2.01(0.42-9.49)$ & .38 & $2.18(0.28-16.82)$ & .45 \\
\hline$\geq 4 \mathrm{~mm}$ & a & .24 & a & .96 \\
\hline \multicolumn{5}{|c|}{ IL-17F localization for mast cells } \\
\hline Extracellular & 1 & & 1 & \\
\hline Intracellular & $4.99(1.28-19.38)$ & .01 & $4.18(1.01-17.26)$ & .04 \\
\hline
\end{tabular}

Abbreviations: CI, confidence interval; HR, hazard ratio; IL, interleukin.

${ }^{\mathrm{a}}$ None of the patients with $<4 \mathrm{~mm}$ depth of invasion died because of their disease.

Figures in boldface indicates statistical significance.

TABLE 7 Cox regression univariate and multivariate analyses of disease-specific survival for patients with late-stage oral tongue squamous cell carcinoma

\begin{tabular}{|c|c|c|c|c|}
\hline Variables & \multicolumn{2}{|c|}{ Univariate analysis } & \multicolumn{2}{|c|}{ Multivariate analysis } \\
\hline$<60$ & 1 & & 1 & \\
\hline$\geq 60$ & $2.99(0.82-10.96)$ & .09 & $2.63(0.60-11.51)$ & .19 \\
\hline \multicolumn{5}{|l|}{ Sex } \\
\hline Male & $1.80(0.60-5.37)$ & .29 & $1.31(0.39-4.33)$ & .65 \\
\hline \multicolumn{5}{|l|}{ Tumor grade } \\
\hline I and II & 1 & & 1 & \\
\hline III & $1.75(0.38-7.94)$ & .46 & $2.18(0.39-11.98)$ & .36 \\
\hline$\geq 4 \mathrm{~mm}$ & $0.41(0.126-1.34)$ & .14 & $0.54(0.15-1.96)$ & .35 \\
\hline \multicolumn{5}{|c|}{ IL-17F localization for mast cells } \\
\hline Extracellular & 1 & & 1 & \\
\hline Intracellular & $3.34(1.11-10.06)$ & .03 & $2.28(0.69-7.48)$ & .17 \\
\hline
\end{tabular}

Abbreviations: CI, confidence interval; HR, hazard ratio; IL, interleukin.

Figures in boldface indicates statistical significance. 
Mast cells produce a large variety of effector molecules. These molecules are released extracellularly either within minutes of activation (acute phase of disease) or over hours or even days (delayed or chronic phase). ${ }^{18}$ Despite the controversial role of mast cells in carcinogenesis, several studies have reported that mast cells play a protective role in human cancers and improve prognosis, such as in colorectal and oral cancers. ${ }^{24-26}$ As for oral tongue cancer, the mast cell count showed significant correlation with the tumor stage but not tumor grade or lymph node metastasis. ${ }^{27}$ Here, we report that extracellular IL-17F from mast cells at the invasion front was significantly associated with improved overall prognosis of patients with oral tongue SCC. This result is supported by the fact that intracellular IL-17F is most probably nonfunctional because of the lack of any known intracellular IL-17F receptors and, thus, cannot initiate ligand-receptor responses. ${ }^{28,29}$ Similar phenomena are also known for other inflammatory molecules, such as histamine. Histamine remains inactive inside the granules of mast cells until its release upon degranulation to the oral mucosal environment. ${ }^{30}$

In conclusion, extracellular mast cell-derived IL-17F has a protective role in oral tongue SCC. It also could separate high-risk from low-risk patients with early-stage oral tongue SCC. Furthermore, we have also demonstrated the importance of the cellular source, distribution, and localization criteria in the histopathological evaluation of tentative molecular biomarkers. Unfortunately, the vast majority of biomarker studies still only evaluate the molecular expression intensity in the cancer cells; even when the tumor microenvironment is counted, only staining intensity is evaluated. Such criteria of the studied molecules should be taken into consideration before implementing their use in routine clinical practice. There are, however, some limitations in our study, such as the use of a semiquantitative immunohistological assessment and the lack of functional IL-17F experiments; performance of such experiments is warranted in the future.

\section{ACKNOWLEDGMENTS}

The authors acknowledge the funders of this study: Sigrid Jusélius Foundation, the Cancer Society of Finland, Oulu University Hospital MRC grant, Emil Aaltonen Foundation, and Helsinki University Central Hospital Research Funds.

\section{ORCID}

Abdelhakim Salem DDS (D) http://orcid.org/0000-0002-94553823

Alhadi Almangush PhD (1Dhttp://orcid.org/0000-0003-4106$314 \mathrm{X}$

Ahmed Al-Samadi PhD (D) http://orcid.org/0000-0003-19382136

\section{REFERENCES}

[1] Marur S, Forastiere AA. Head and neck squamous cell carcinoma: update on epidemiology, diagnosis, and treatment. Mayo Clin Proc. 2016;91:386-396.

[2] Ferlay J, Soerjomataram I, Dikshit R, et al. Cancer incidence and mortality worldwide: sources, methods and major patterns in GLOBOCAN 2012. Int J Cancer. 2015;136:E359-E386.

[3] Bray F, Sankila R, Ferlay J, Parkin DM. Estimates of cancer incidence and mortality in Europe in 1995. Eur J Cancer. 2002; 38:99-166.

[4] Parkin D, Bray F, Ferlay J, Pisani P. Global cancer statistics, 2002. CA Cancer J Clin. 2005;55:74-108.

[5] Sankaranarayanan R, Ramadas K, Amarasinghe H, Subramanian S, Johnson N. Oral cancer: prevention, early detection, and treatment. In: Gelband H, Jha P, Sankaranarayanan R, Horton S, eds. Cancer: Disease Control Priorities. Washington, DC, The International Bank for Reconstruction and Development/The World Bank, 2015.

[6] Sciubba JJ. Oral cancer: the importance of early diagnosis and treatment. Am J Clin Dermatol. 2011;2:239-251.

[7] Korn T, Bettelli E, Oukka E, Kuchroo VK. IL-17 and Th17 cells. Аппи Rev Immunol. 2009;27:485-517.

[8] Tartour E, Fossiez F, Joyeux I, et al. Interleukin 17, a T-cellderived cytokine, promotes tumorigenicity of human cervical tumors in nude mice. Cancer Res. 1999;59:3698-3704.

[9] Wei T, Cong X, Wang XT, et al. Interleukin-17A promotes tongue squamous cell carcinoma metastasis through activating miR-23b/versican pathway. Oncotarget. 2017;8:6663-6680.

[10] Tong Z, Yang XO, Yan H, et al. A protective role by interleukin17F in colon tumorigenesis. PLoS One. 2012;7:e34959.

[11] Al-Samadi A, Moossavi S, Salem A, et al. Distinctive expression pattern of interleukin-17 cytokine family members in colorectal cancer. Tumor Biol. 2015;37:1609-1615.

[12] Benchetrit F, Ciree A, Vives V, et al. Interleukin-17 inhibits tumor cell growth by means of a T-cell-dependent mechanism. Blood. 2002;99:2114-2121.

[13] Xie Y, Sheng W, Xiang J, Ye Z, Yang J. Interleukin-17F suppresses hepatocarcinoma cell growth via inhibition of tumor angiogenesis. Cancer Invest. 2010;28:598-607.

[14] Ding L, Hu EL, Xu YJ, et al. Serum IL-17F combined with VEGF as potential diagnostic biomarkers for oral squamous cell carcinoma. Tumor Biol. 2015;36:2523-2529.

[15] McShane LM, Altman DG, Sauerbrei W, Taube SE, Gion M, Clark GM. Reporting recommendations for tumor marker prognostic studies (REMARK). J Natl Cancer Inst. 2005;97:1180-1184.

[16] Coussens LM, Werb Z. Inflammation and cancer. Nature. 2002; 420:860-867.

[17] Kuper H, Adami HO, Trichopoulos D. Infections as a major preventable cause of human cancer. J Intern Med. 2000;248:171-183.

[18] Khazaie K, Blatner NR, Khan MW, et al. The significant role of mast cells in cancer. Cancer Metastasis Rev. 2011;30:45-60.

[19] Salem A, Almahmoudi R, Listyarifah D, et al. Histamine H4 receptor signalling in tongue cancer and its potential role in oral carcinogenesis - a short report. Cell Oncol (Dordr). 2017;40(6):621-630. 
[20] Lin AM, Rubin CJ, Khandpur R, et al. Mast cells and neutrophils release IL-17 through extracellular trap formation in psoriasis. J Immunol. 2011;187:490-500.

[21] Eiró N, Vizoso FJ. Inflammation and cancer. World J Gastrointest Surg. 2012;4:62-72.

[22] Al-Samadi A, Awad SA, Tuomainen K, et al. Crosstalk between tongue carcinoma cells, extracellular vesicles, and immune cells in in vitro and in vivo models. Oncotarget. 2017;8(36):60123-60134.

[23] Dayan D, Salo T, Salo S, et al. Molecular crosstalk between cancer cells and tumor microenvironment components suggests potential targets for new therapeutic approaches in mobile tongue cancer. Cancer Med. 2012;2:128-140.

[24] Nielsen HJ, Hansen U, Christensen IJ, Reimert CM, Brunner N, Moesgaard F. Independent prognostic value of eosinophil and mast cell infiltration in colorectal cancer tissue. J Pathol. 1999;189:487-495.

[25] Hedström G, Berglund M, Molin D, et al. Mast cell infiltration is a favourable prognostic factor in diffuse large B-cell lymphoma. Br J Haematol. 2007;138:68-71.

[26] Attramadal CG, Kumar S, Gao J, Boysen ME, Halstensen TS, Bryne M. Low mast cell density predicts poor prognosis in oral squamous cell carcinoma and reduces survival in head and neck squamous cell carcinoma. Anticancer Res. 2016;36:5499-5506.

[27] Henriksson R, Bjermer L, Frojd O, Franzen L, Gustafsson H. Mast-cell frequency within tumor correlates to the stage of tongue cancer. Oncol Rep. 1994;1:433-434.

[28] Gaffen SL. Structure and signalling in the IL-17 receptor family. Nat Rev Immunol. 2009;9:556-567.

[29] Chang SH, Dong C. IL-17F: regulation, signaling and function in inflammation. Cytokine. 2009;46:7-11.

[30] Salem A, Rozov S, Al-Samadi A, et al. Histamine metabolism and transport are deranged in human keratinocytes in oral lichen planus. Br J Dermatol. 2017;176:1213-1223.

How to cite this article: Almahmoudi R, Salem A, Sieviläinen M, et al. Extracellular interleukin-17F has a protective effect in oral tongue squamous cell carcinoma. Head \& Neck. 2018;40:2155-2165. https://doi. org/10.1002/hed.25207 